\title{
Geociências
}

\section{Quantitative colour analyses using digital specification technique for Mármore Bege Bahia, a representative Brazilian ornamental limestone of breccia-like texture}

\author{
Akihisa Motoki \\ Departamento de Mineralogia e Petrologia Ígnea, Universidade do Estado do Rio de Janeiro \\ E-mail:amotoki@yahoo.com \\ José Luíz Peixoto Neves \\ Departamento de Mineralogia e Petrologia Ígnea, Universidade do Estado do Rio de Janeiro \\ E-mail: jl.pneves@terra.com.br \\ Thais Vargas \\ Departamento de Mineralogia e Petrologia Ígnea, Universidade do Estado do Rio de Janeiro \\ Laboratório de Geologia Marinha, Universidade Federal Fluminense.E-mail: thais@igeo.uff.br
}

\section{Resumo}

Os autores realizaram ensaios com base em especificações digitais de cores em rocha total e em pontos com o auxílio de scanner, computador e Wilbur, um software original para análises quantitativas de cores, para Mármore Bege Bahia, um calcário ornamental com textura brechóide explotado na região centro-norte da Bahia. Essa rocha é caracterizada pela cor amarela clara ( $B=83.4)$, vívida $(S=10.8)$, relativamente homogênea $(\sigma(\mathrm{H})=3.9 ; \sigma(\mathrm{B})=6.5)$, tendendo ligeiramente a cor de laranja ( $\mathrm{H}=35.8)$. A variação das cores é limitada em $10 \%$ em clareza e as cores projetadas no diagrama SB (saturação-clareza) apresentam uma configuração linear, com taxa de declinação -1.6. Esse fenômeno é comum em minerais com clivagem altamente desenvolvidas e atribuído à reflexão aleatória na superfície da rocha ou reflexão subsuperficial dentro do mineral de calcita. Os blocos desse calcário extraídos a partir das pedreiras comumente contêm numerosas cavidades e a técnica de preenchimento por resina é freqüentemente aplicada. Dessa forma, recomenda-se que as cores da resina sejam adequadamente ajustadas conforme a configuração linear acima citada para que a rocha remendada tenha aspecto visual próximo ao natural.

Palavras-chave: Mármore Bege Bahia, especificação de cor, HSB, Wilbur, FLD.

\begin{abstract}
The authors have performed based on digital quantitative colour specification in whole rock and spots using a scanner, a computer, and original colour analysing software Wilbur for Mármore Bege Bahia, an ornamental limestone of breccia-like texture exploited in the centre-north region of Bahia, Brazil. The rock is characterised by light $(B=83.4)$, vivid $(S=10.8)$, and relatively homogeneous $(\sigma(H)=3.9 ; \sigma(B)=6.5)$ yellow, tending slightly to orange $(H=35.8)$. The whole rock colour variation is limited to within $10 \%$ in brightness, and the colours plotted on the SB (saturationbrightness) diagram constitute a linear trend, with a declination rate of -1.6. This phenomenon is common in minerals with highly developed cleavage and attributed to random reflection on rock surface and subsurface reflection in the mineral interior of calcite. The rock blocks extracted from the quarries commonly have a large number of cavities and the resin-fill technique is frequently applied. It is recommended that the resin colours be adjusted adequately according to the abovementioned linear trend in order to make the patched limestone visually appear as the natural one.
\end{abstract}

Keyword: Mármore Bege Bahia, colour specification, HSB, Wilbur, FLD. 


\section{Introduction}

In recent years, quarry production, factory processing, and civil construction application of Brazilian granites and marbles for decorative uses, so-called “ornamental rocks”, are remarkably growing upwards. In the $21^{\text {st }}$ Century, Brazilian rock industries have rapidly expanded their market in foreign countries. This success can be attributed to the introduction of high-technology machinery that enables best-quality cutting and polishing whereupon meeting the high standards of industrially developed countries.

No doubt, the visual aspect is a most important factor for ornamental rocks because it defines commercial value. Many Brazilian ornamental rocks are highly evaluated because of their relevant colour, such as: Granito Vermelho Capão Bonito (red), Granito Preto São Gabriel (black), Granito Verde Peacock (green), and Granito Branco Ceará (white). In order to attend the foreign market, high-precision quality control in rock colour is an important condition. This technique keeps colour homogeneity of the products in the same lot. The technique of quantitative colour measuring with numeral outputs is called “colour specification”.

\section{Digital colour specification}

Motoki et al. (2000) proposed a theoretical method for physical colour specification in true-colour mode, about 16 million colours, using an image scanner and a computer and proposed an HSB (hue, saturation, brightness) chromaticity system for output parameters instead of the RGB (red, green, blue) system, because of strong colour dispersion from the rock surface. In fact, this colour dispersion is a specific problem for ornamental rock, not being observed in the colour of animals, plants and artificial objects. The HSB system joins the efficiently quantitative merits of the CIE (Comission Internacionale de L 'Éclariage) standard (adopted by colour industries as physical parameters) and the emotional merits of the Mansell colour system (diffused by artists as the mental colour standard).

Motoki et al. (2003a; b) developed an original computer software for colour specification "Wilbur ver.1.0”. This linecommand level software transformed the above-mentioned theory into an objective and practical colour specification technology. Application of this technology enabled the classification of principal Brazilian ornamental rocks by means of the HSB system for physical whole rock colour. The ornamental rocks are classified, at first, by means of saturation, $S$ parameter, into the following categories: greyscale, $\mathrm{S}<4$; slight colour, $4<\mathrm{S}<6$; low-colour, $6<\mathrm{S}<8$; middle-colour, $8<\mathrm{S}<10$; high-colour $\mathrm{S}>10$. The rocks with low saturation are subclassified by brightness, B parameter into: black $\mathrm{B}<25$; dark grey, $25<\mathrm{B}<55$; light grey, $55<\mathrm{B}<85$; white $\mathrm{B}>85$. The rocks with high saturation are subclassified by hue, $\mathrm{H}$ parameter, into: red, $0<\mathrm{H}<20$; orange, $20<\mathrm{H}<40$; yellow $40<\mathrm{H}<60$. The quantitative divisions between the categories were defined according to qualitative evaluation and law of experience of the stone market.

This technique is valid for various types of ornamental rocks, such as granites (e.g. Motoki \& Melo, 2005), marbles (Motoki et al. 2005a) and basalts (Motoki et al. 2005b), but it is still in development. Motoki et al. (2005a) mentioned some still-unsolved problems in colour specification of ornamental rocks, such as: technical difficulty for low saturation rocks, the so-called "charnockite problem" (CHR); colour dispersion caused by random reflection on rock surface and subsurface, called the "feldspar problem" (FLD); different mental impact of the greyscale rocks of the same brightness, the "syenite problem” (SYN); and colour specification difficulty caused by complexly interfingered texture, the "migmatite problem” (MGT). In addition, physical colour systems, such as HSB and RGB, are quantitatively not equivalent to mental ones (MNT). Therefore in the future a colour specification method based on a mental chromaticity system, such as $l^{*} u^{*} v^{*}$, must be developed, replacing the HSB physical colour system.

This paper presents a physical colour analyses based on the HSB system for Mármore Bege Bahia, a representative Brazilian limestone of breccia-like texture, where the whole rock colour and spot colour of the samples were studied, and discusses the genesis of colour variation of this ornamental limestone.

\section{Mármore Bege Bahia}

Mármore Bege Bahia is highly attractive stone for Brazilian architects, being applied widely for decorative interior uses and wall coating (Azambuja \& Silva 1977; Bahia, 1994; Mendes \& Vasconcellos, 1994; Azevedo, 2001). This rock corresponds petrologically to nonmetamorphic limestone and is characterised by its light yellow colour and breccia-like texture. Surface polish is applied to this limestone either for external uses i.e. wall coating or internal ones e.g. furniture. (Figure 1).

The geological setting and the geneses of Mármore Bege Bahia has been intensively studied by Companhia Baiana de Pesquisa Mineral - CBPM (Mineral Exploration Company of the State of Bahia), with the objectives of mining improvement and market expansion including possibly to foreign countries (Penha 1994; Ribeiro et al. 2002). The extraction area is located in the centre-north region of the State of Bahia, northeast Brazil, represented by Ourolândia, Campo Formoso, Mirangaba, Jacobina and Umburanas (Figure 2).

The ornamental rock ores is found in the Caatinga Formation. The carbonate material originates in late Precambrian limestone of the Salitre Formation and physical, chemical, and biological processes of subsurface-formed characteristic breccia-like material. The age of diagenesis and above-mentioned supergenic processes is estimated to be Miocene at the base of the Caatinga Formation and Pleistocene at the top. Underground water eventually creates 
many tube or fissure-like vacancies in this limestone and small ones are filled with chalcedony. Because of this genesis, the Caatinga Formation is classified to be calcrete or travertine (Penha, op.cit.; Figure 3).

The total mineral reserve is estimated to be $6,820,000 \mathrm{~m}^{3}$, and its mean annual production between 1996 and 2000 was about $200,000 \mathrm{~m}^{3}$ (Ribeiro et al. op.cit.). Representative quarry price in rock blocks is about $\mathrm{R} \$ 180 / \mathrm{m}^{3}$ (US\$60.00). Each cubic metre of the rock block produces $32 \mathrm{~m}^{2}$ of rough-surface slabs, which cost approximately $\mathrm{R} \$ 20 / \mathrm{m}^{2}$ (US\$6.67). The cost for surface polish is about $\mathrm{R} \$ 10 / \mathrm{m}^{2}$ (US\$3.33).

\section{Methodology of present colour analyses}

Four slabs of Mármore Bege Bahia with polished surface, PX1, PX2, PX3, and PX4, are analysed either for whole rock colour or for spot material colours, at the Petrographical
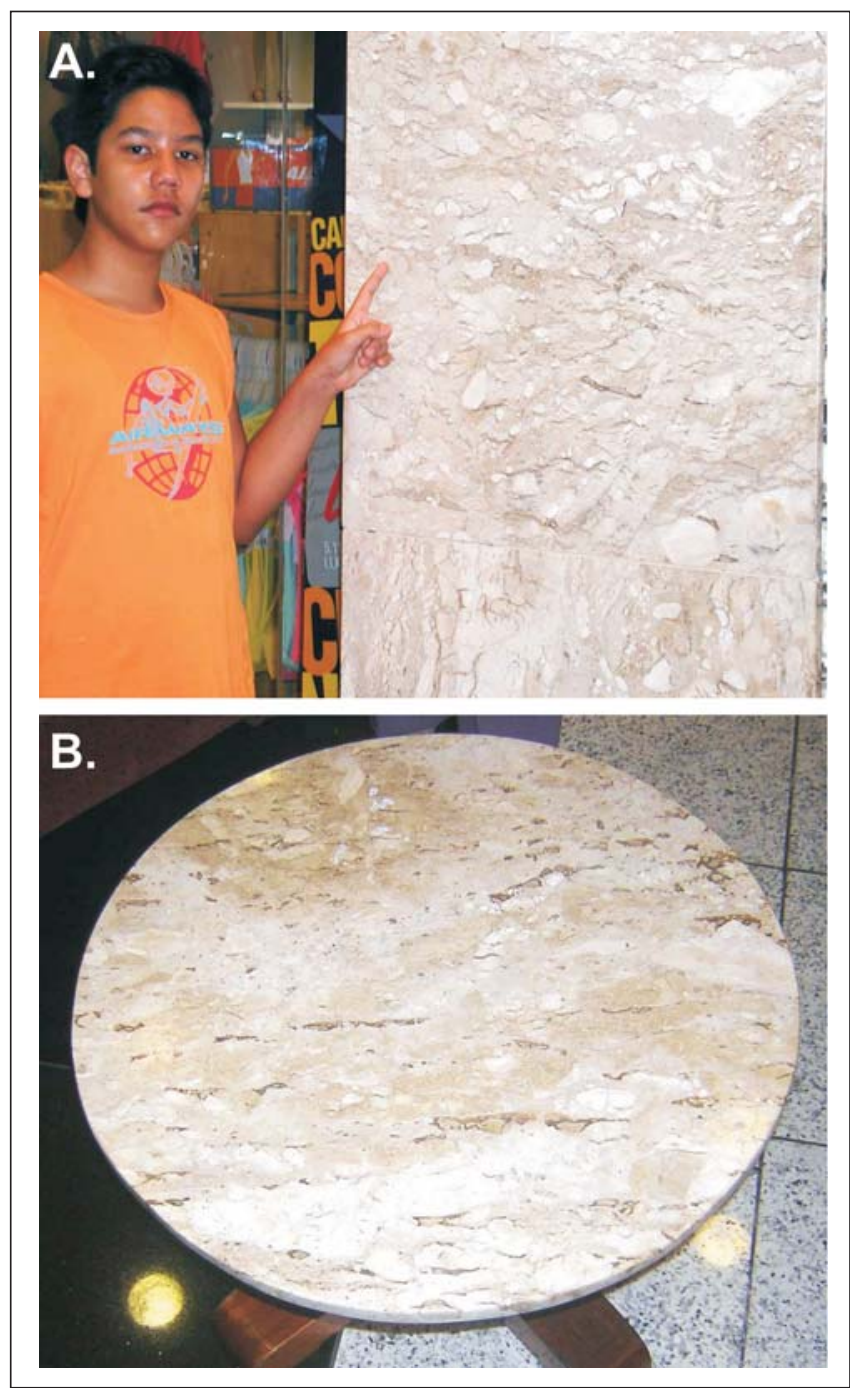

Figure 1 - Application examples of Mármore Bege Bahia to external uses, e.g. wall coating (A), and internal ones, e.g. stone table, (B).

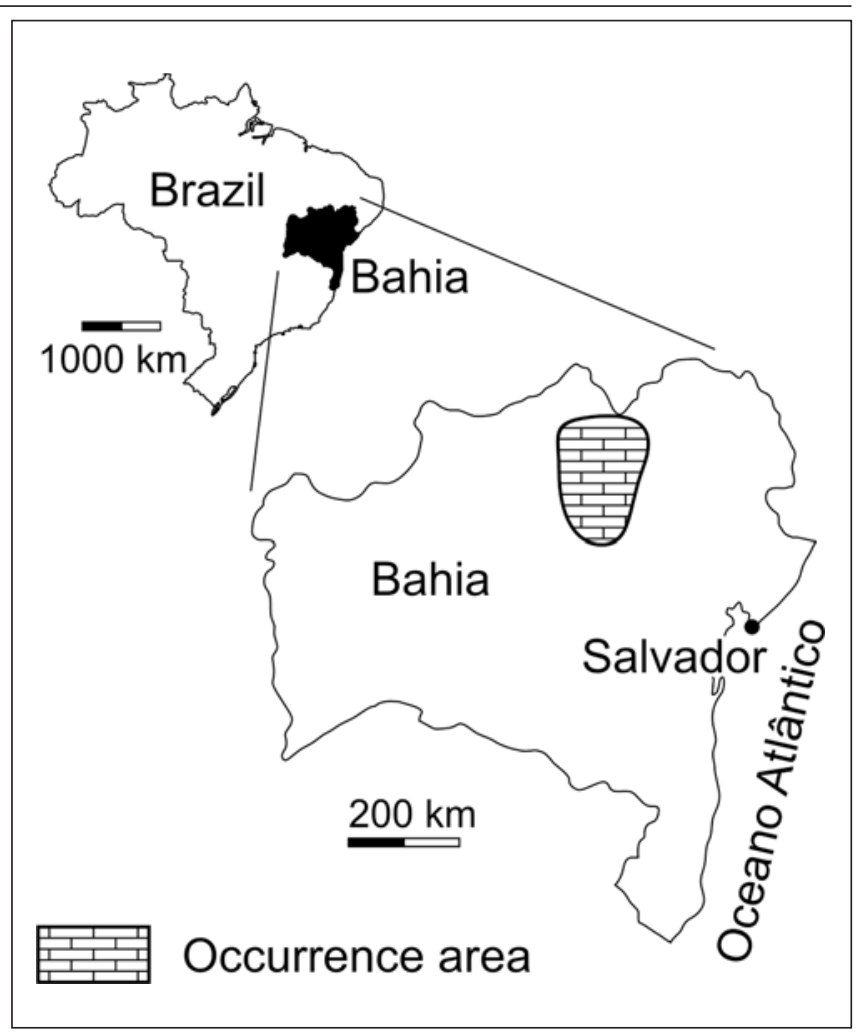

Figure 2 - Locality map for Mármore Bege Bahia occurrence area, centre-north region of the State of Bahia, northeast Brazil.



Figure 3 - Schematic cross section of Mármore Bege Bahia natural stone ore simplified from Geoexplore (2002), showing the relation between mother limestone of Salitre Formation, late Precambrian, and calcrete deposito of Caating Formation, Miocene to Pleistocene. 
Laboratory of the Department of Mineralogy and Igneous Petrology at the Rio de Janeiro State University (LPETRO/UERJ). The scanner applied to the analyses is HPтм 6200C, and the personal computer is equipped with AMD $^{\mathrm{TM}}$ Barton $^{\mathrm{TM}} 2600 \mathrm{CPU}$ and of 512 Mbytes RAM. The scanning optical resolution is $600 \mathrm{DPI}$ and moderated to 75 DPI after scanning, according to the recommendation of Motoki et al. (2003a; b). The analysed area of each polish slab is $4 \times 4$ inches. Each moderated pixel of $75 \mathrm{DPI}, 0.33 \times 0.33 \mathrm{~mm}$, makes one colour datum.

The graphic software Adobe Photoshop $^{\text {TM }} 7.0$ is applied to image preprocessing to make Windows ${ }^{\mathrm{TM}} \mathrm{BMP}$ files necessary for the Wilbur operation. The areas accidentally streaked or stained and the vacancies filled artificially by resin are eliminated from the colour analyses by means of the exclusion filter layer elaborated by CorelDraw $^{\mathrm{TM}} 10$. That is, only the area painted by red on the Figure 4B is selected from the original rock image, Figure 4A, for the colour analyses.
The numbers of colour data measured for the whole rock analyses for the samples PX1, PX2, PX3, and PX4 are, respectively, 89703, 86697, 84741, and 89370. The numbers of colour data for spot analyses for dark clasts, light clasts, mixture zones, and chalcedony fracturefill for the sample PX1 are 40827, 26584, 15104, and 5641, and those for the sample PX2, 21972, 19011, 44117, and 1866. This immense number of colour analyses is enabled with help of Wilbur.

\section{Whole rock colour}

The whole rock colour analyses indicates that the general colour of this limestone is slightly reddish yellow (mean $\mathrm{H}=35.8$ ) with relatively high saturation (mean $S=10.8$ ) and high brightness (mean $\mathrm{B}=83.4$; Table 1; Figure 5). However, the saturation is less than several other Brazilian marbles and granites of vivid colour, e.g. Mármore Rosa Cachoeiro ( $S=14.9)$, Granito Vermelho Itu ( $S=15.1)$, and Granito Vermelho Bragança Paulista ( $\mathrm{S}=16.0$ ). This rock is not classified as a white marble because of its high saturation. Similar characteristics are observed in Mármore Amarelo Aurora ( $\mathrm{S}=9.3$ ), a typical Brazilian yellow marble $(\mathrm{B}=89.4)$. The brightness is very high, $\mathrm{B}=83.4$, being close to white rock category (B>85).

As a general characteristic of marbles, the colours of the Mármore Bege Bahia are relatively homogenous, in spite of its breccia-like texture. The standard deviation of brightness, $\sigma(B)=6.4$, is much lower than that of granites, because this limestone contains no biotite and hornblende. However the value is higher than the other colour marbles, due to complex breccia-like texture. The whole rock hue corresponds to yellow colour tending slightly to orange (mean $\mathrm{H}=35.8$ ). In spite of the brightness variation, the hue is of low dispersion, $\sigma(\mathrm{H})=3.9$. Eventually, the yellow colour of Mármore Bege Bahia is less expressive and less homogeneous than Mármore Amarelo Aurora with its homogeneous texture and relevant yellow colour, $\mathrm{H}=49.6$ and $\sigma(\mathrm{H})=3.1$.

\section{A. Original rock image}

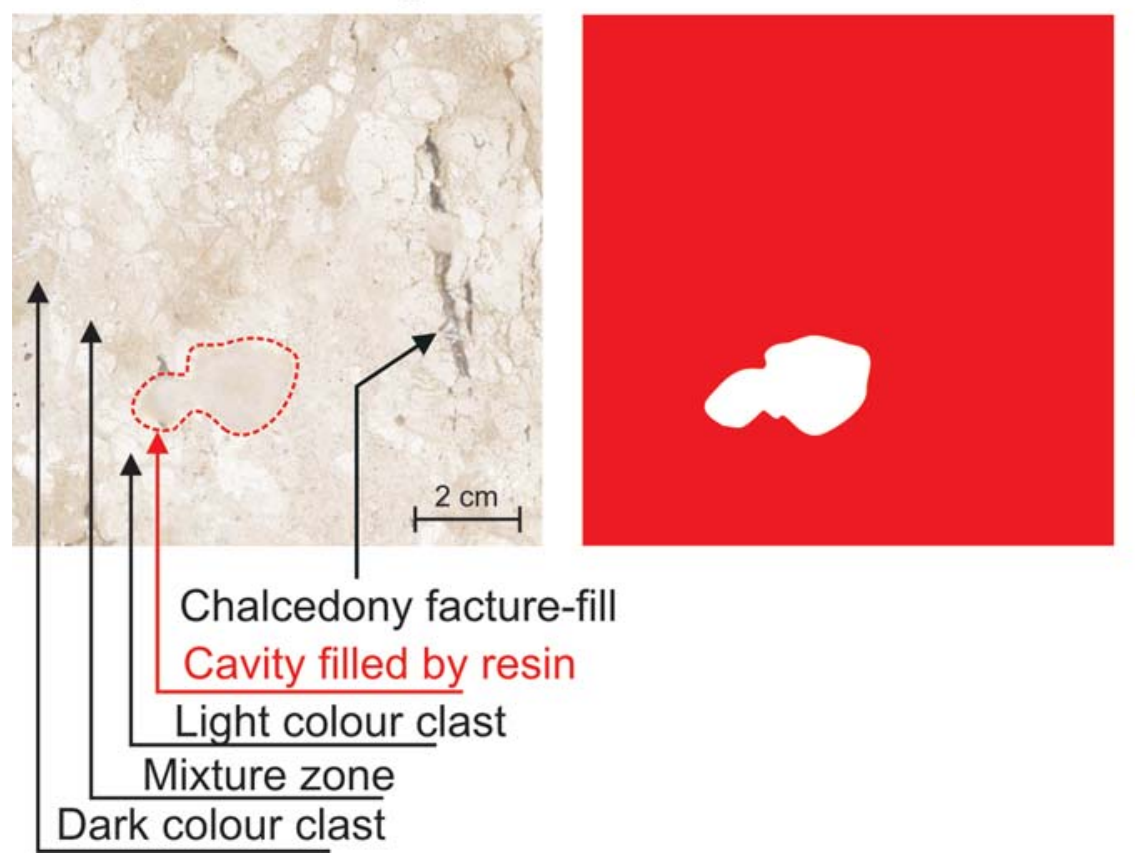

\section{Selection filter}

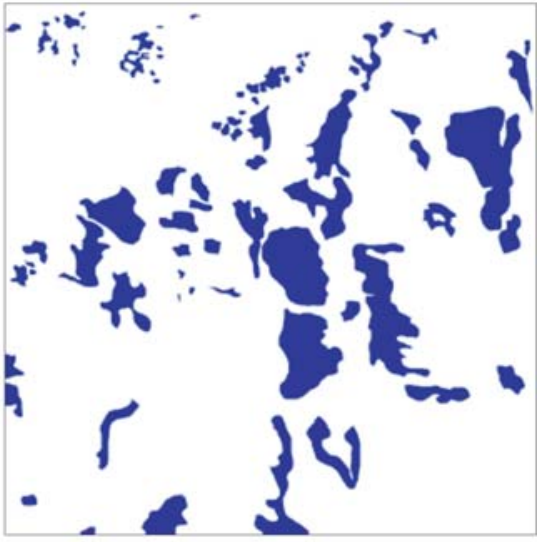

Figure 4 - Original scanner image of the rock (A), exclusion of streaked zones, stained areas, and vacancy spaces by means of elimination filter (B), and selection filter for light colour clasts (C). 
Akihisa Motoki et al.

Colour variation, with special attention to brightness is analysed using the above-mentioned four samples. Simple naked eye observation indicates that PX1 is dark, PX2 is medium, and PX3 and PX4 are light (Figure 6). This tendency appears clearly in the specified mean brightness of PX1, PX3, and PX4, respectively in mean $\mathrm{B}=78.4,79.9$, and
$\mathrm{B}=86.6$. The quantitative difference in the specified brightness is $2 \sim 10 \%$ and it seems to be less expressive than the mental impression.

The sample PX2 is of medium colour according to simple naked eye observation and characterised by a complex breccia-like texture composed of a mixture of dark and light material. But, measured whole rock mean brightness of this sample, $\mathrm{B}=88.8$, is higher than $\mathrm{PX} 3$ and PX4, of apparently light colour. This contradiction can be attributed to abovementioned complex breccia-like texture, which may cause a high degree of random reflection, corresponding to the above-mentioned FLD (feldspar problem) effect.

Table 1 - Quantitative physical colour analyses for Marmore Bege Bahia in whole rock and in spots of the material, in comparison with the whole colour of other ornamental rocks.

\begin{tabular}{|c|c|c|c|c|c|c|}
\hline Mármore Bege Bahia & Whole rock colour & $\mathbf{H}$ & $1 \sigma(H)$ & $\mathbf{S}$ & B & $1 \sigma(B)$ \\
\hline $\mathrm{PX} 1$ & & 36.8 & 2.0 & 12.8 & 78.4 & 7.2 \\
\hline $\mathrm{PX} 2$ & & 34.9 & 5.8 & 7.6 & 88.8 & 6.6 \\
\hline PX3 & & 31.0 & 3.8 & 12.0 & 79.9 & 6.1 \\
\hline PX4 & & 40.5 & 4.2 & 10.7 & 86.6 & 5.9 \\
\hline Mean & & 35.8 & 3.9 & 10.8 & 83.4 & 6.4 \\
\hline $\mathrm{PX} 1$ & spot colour & & & & & \\
\hline Dark clasts & & 36.5 & 1.5 & 14.1 & 74.4 & 4.5 \\
\hline Light clasts & & 37.0 & 1.5 & 13.1 & 78.3 & 5.6 \\
\hline Mixture zone & & 37.6 & 2.5 & 10.1 & 86.3 & 5.9 \\
\hline Chalcedony & & 35.1 & 4.9 & 11.3 & 72.5 & 9.0 \\
\hline $\mathrm{PX} 2$ & spot colour & & & & & \\
\hline Dark clasts & & 35.7 & 5.1 & 10.1 & 83.6 & 5.4 \\
\hline Light clasts & & 34.8 & 2.8 & 8.0 & 88.7 & 4.4 \\
\hline Mixture zone & & 34.5 & 6.8 & 6.6 & 91.3 & 5.0 \\
\hline Chalcedony & & 33.6 & 10.6 & 8.7 & 70.1 & 12.6 \\
\hline \multicolumn{7}{|l|}{ Marble } \\
\hline Mármore Amarelo Aurora & yellow limestone & 49.6 & 3.1 & 9.3 & 89.4 & 2.7 \\
\hline Mármore Rosa Cachoeiro & pink marble & 17.0 & 2.7 & 14.9 & 74.4 & 4.9 \\
\hline Mármore Branco Cintilante & white marble & 91.6 & 16.3 & 2.4 & 92.1 & 3.0 \\
\hline \multicolumn{7}{|l|}{ Granite } \\
\hline Granito Vermelho Itu & red granite & 19.3 & 3.4 & 15.1 & 44.3 & 9.0 \\
\hline Bragança Vermelho Bragança & red granite & 19.7 & 2.9 & 16.0 & 48.3 & 10.2 \\
\hline Granito Marrom Caldas & brown cyanite & 21.5 & 6.8 & 7.4 & 39.6 & 8.8 \\
\hline Granito Cinza Andorinha & grey gernite & 316.9 & 80.0 & 2.5 & 63.7 & 22.3 \\
\hline Granito Cinza Ás de Paus & grey nepheline cyanite & 41.5 & 16.5 & 4.8 & 60.2 & 15.2 \\
\hline Inada Granite & grey granite & 44.1 & 42.8 & 2.7 & 71.3 & 12.4 \\
\hline
\end{tabular}




\section{Spot colour for the fabrics}

The breccia-like texture of Mármore Bege Bahia is a most important visual feature and made up of dark and light material (Figure 6). In order to analyse the rock colour in detail, the authors applied spot colour analyses, utilising the great advantage of Wilber. Four types of targets are selected for the spot analyses: 1) dark clast material; 2) light clast material; 3) mixture zone; 4) chalcedony fracture-fill. Spots are analysed in a dark-coloured sample, PX1, and a medium-colour one, PX2.

The spot colour analyses with special attention to brightness shows that the pixel colours for the dark clasts of PX1 are scattered mainly in a range between $B=64 \sim 88$, with a mean value of $\mathrm{B}=74.4$. The colour data for the light clasts of the same sample are present in $B=65 \sim 93$, mean $B=78.3$, and those for the mixture zone, $\mathrm{B}=71 \sim 98$, mean $\mathrm{B}=86$.3. In the case of PX2, the pixel colour for the dark clasts are located mainly in $B=69 \sim 98$, mean $B=83.6$, those for light clasts, $B=75 \sim 100$, mean $B=88.7$, and those for the mixture zone, $\mathrm{B}=72 \sim 100$, mean 93.1 (Table 1; Figure 5; 7). This fact indicates that the apparent dark colour of PX1 is due to the darker colour of all types of PXI material as compared to those of PX2, and not, because of the larger proportion of dark cluster area.

Either for PX1 or PX2, the mean brightness of the mixture zones, respectively $\mathrm{B}=86.3$ and $\mathrm{B}=91.3$, is significantly higher than that of the areas of light colour clasts, $\mathrm{B}=78.3$ and $\mathrm{B}=88.7$. This high brightness of the mixture zones can be justified by the FLD effect, in a similar way for the high brightness of the whole rock colour of PX2. In both cases, the objects of higher brightness are characterised by complex breccia-like texture, which is expected to have a high degree random reflection.

The chalcedony fracture-fill has low brightness, scattering in a range of $\mathrm{B}=52 \sim 95$, in mean $\mathrm{B}=72.5$, for $\mathrm{PX} 1$, and $\mathrm{B}=40 \sim 100$, mean $\mathrm{B}=70.1$, for PX2 (Table

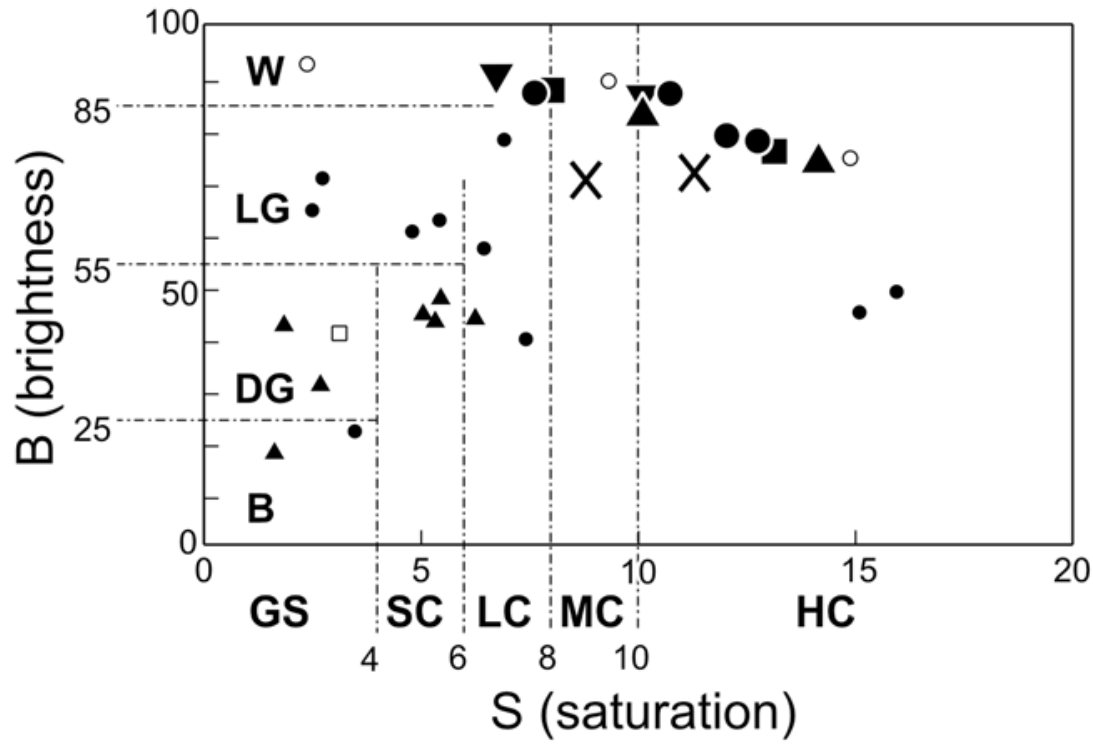

\section{Mármore Bege Bahia}

- Whole rock $\quad$ Dark clast
Light clast Chalcedony fracture-fill

- Granites, syenites, granulites, gneisses - Bahia sodalite syenite $\circ$ marbles - Felsic porphyry, commercially called "Basalt"

Figure 5 - SB (saturation-brightness) diagram plot for mean colours of Mármore Bege Bahia in whole rock and fabrics, in comparison with other ornamental rocks. Colour classification categories: GS, greyscale $(S<4)$; SC, slight-colour $(4<S<6)$; LC, lowcolour $(6<S<8)$; MC, middle-colour $(8<S<10)$; HC, high-colour $(S>10)$; B, black $(B<25)$; DG, dark grey $(25<B<55)$; LG, light grey $(55<B<85)$; W, white $(B>85)$. The classification categories and data of other ornamental rocks are based on Motoki et al. (2003a; b).

1; Figure 7). However, their mean hue, $\mathrm{H}=35.1$ and $\mathrm{H}=33.6$, is similar to that of whole rock one, $\mathrm{H}=33.6$ and $\mathrm{H}=34.9$. This hue value and very wide dispersion of saturation and brightness (Figure 7) may be due to the influence of whole rock colour to semi-transparent chalcedony.

\section{Discussion}

In total, 525,633 colour analyses on whole rock and spot have been done for Mármore Bege Bahia. The results reveal that the measured colours constitute a linear trend pattern on the saturation brightness diagram (SB diagram; Figure
5; 7), showing than the colours with low saturation tend to have high brightness. The extension of this line trend toward the $S=0$ vertical line gets to the point of pure white, $S=0$ and $B=100$. The declination ratio of brightness to saturation increase, $\Delta S / \Delta \mathrm{B}$, is approximately -1.6 (Figure 7 ). This phenomenon is observed widely in the alkaline feldspar colour of granitic rocks, called FLD effect ("feldspar problem"; Motoki et al. 2005a).

The original natural colour of the calcite mineral in this limestone might be of relatively high saturation and low brightness, such as $\mathrm{S}=15$ and $\mathrm{B}=74$ or of 
slightly higher saturation and lower brightness. This colour is pulled toward pure white in different degrees because of the random reflection on rock surface and subsurface reflection of the mineral interior. In fact, carbonate minerals have well-developed cleavage plains and show relevant FLD effect.

\section{Conclusion}

The quantitative colour analyses for Mármore Bege Bahia indicates that the colour of this rock is characterised by light ( $B=83.4)$, vivid $(S=10.8)$, and relatively homogeneous $(\sigma(\mathrm{H})=3.9$; $\sigma(B)=6.5)$ yellow, tending slightly to orange $(\mathrm{H}=35.8)$. The colour homogeneity is specific in marbles and generally not found in granites. The measured colour variation between the apparently dark sample, PX1, and the relatively light one, $\mathrm{PX} 2$, is $2 \sim 10 \%$ in brightness. The linear trend observed in the SB diagram, with declination ration of -1.6, is attributed to random reflection on rock surface and subsurface reflection of the calcite mineral interior. This phenomenon, called FLD effect, is common in minerals with a welldeveloped cleavage (Motoki et al. 2005).

The blocks of this limestone extracted from the quarries usually contain many cavities, and therefore, a resin cavity-fill technique is frequently applied. In order to make the patched limestone have its visual aspect close to the natural one, the resin colour should be adjusted adequately according to above-mentioned linear trend.

\section{Acknowledgement}

The authors are grateful to Engineer Lóris Lodir Zucco, of the Rio de Janeiro Federal Rural University (CTUR/UFRRJ) for the helpful advice about ornamental dimension stone application to civil construction from the viewpoint of material engineering and to Kenji Freire Motoki, of the Associação Educacional Plínio Leite, for support in intelligence technology, either as hardware or software.
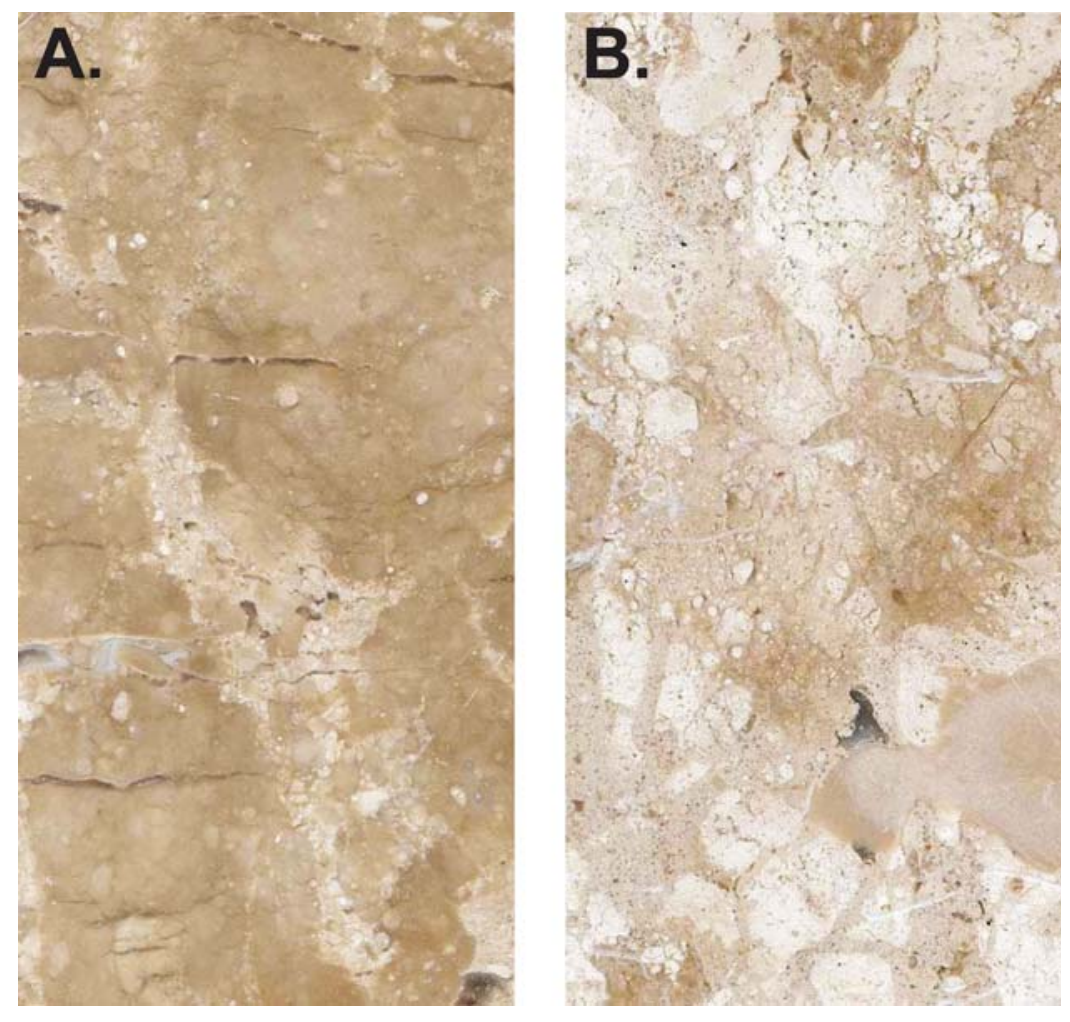

Figure 6 - Surface view of relatively dark sample, PX1 (A), and light one, PX2 (B), of the Mármore Bege Bahia.



\section{Dark clasts}

Mixture zones
Light clasts

\section{Chalcedony}

Figure 7 - Data concentration areas on SB diagram for measured colours of the material: D1, dark clasts of PX1 composed of 40827 data; D2, dark clasts of PX2, 21972; L1, light clasts of PX1, 26584; L2, light clasts of PX2, 19011; M1, mixture zones of PX1, 15104; M2, mixture zones of PX2, 44117; C1, chalcedony fracture-fills of PX1, 5641; CA2, chalcedony fracture-fills of PX2, 1866. Other signs are the same as Figure 5. 


\section{Bibliography}

AZAMBUJA, J.C., SILVA, Z.C. Perfil analítico dos mármores e granitos. Boletim DNPM, v. 38. Brasília, 1977. 64P.

AZEVEDO, H.C.A.. Panorama do setor de rochas ornamentais do Estado da Bahia. Série rochas e minerais industriais: Avanços e transferência tecnológica em rochas ornamentais. Salvador: CEI'EM, 2001.

BAHIA. Catálogo de rochas ornamentais da Bahia-Brasil. Secretaria da Indústria Comércio e Turismo do Estado da Bahia, SGM, 1994.

GEOEXPLORE CONSULTORIAE SERVIÇOS LTDA. Investigação geológica e ambiental dos depósitos e áreas da ocorrências do mármore Bege Bahia na região situada entre os municípios de Ourolândia e Jacobina, a $S$ e Campo Formos, a N. Salvador: CBMP/COMIM, 2002. 135p.

MENDES, A.C.F., VASCONCELLOS, H.G. Panorama de rochas ornamentais da Bahia. Salvador: SICT/SGM, 1994.

MOTOKI A., VARGAS T., NEVES J.L.P., ZUCCO L.L. Quantitative analyses of rock and mineral surface color for ornamental and semi-ornamental rocks using image scanner. Japanese Magazine of Mineralogical and Petrological Sciences, v. 32, n. 1, p. 12-22, 2003a.

MOTOKI A., VARGAS T., PEIXOTO J.L.N. Análise quantitativa das cores de feldspato alcalino, nefelina e sodalita em rochas ornamentais. Mineração Metarulgia, v. 554, n. 6, p. 14-30, 2000.

MOTOKI, A., ARGAS, T., EVES, J.L.P., ZUCCO, L.L. Pietre naturali classificate per colori, una técnica de misurazione quantitativa del colore per rocce ornamentali e semi-ornamentali, utilizzando scanner e computer. L'Informatore del Marmistas, v. 493, p. 6-16, 2003b.

MOTOKI, A., MELO. D.P. Extraction, reforming and applications of the Inada Granite, a traditional Japanese ornamental rock of light grey colour. Anais do Primeiro Congresso Internacional de Rochas Ornamentais, CD, 2005.

MOTOKI, A., ZUCCO, L.L. Digital colour specification for ornamental rocks using image scanner: its technical challenge, ongoing develpment, further innovation, and application. Anais do Primeiro Congresso Internacional de Rochas Ornamentais, CD, 2005a.

MOTOKI, A., ZUCCO, L.L., FREITAS, A. Ornamental and artistic applications of basalt, an attractive variation of porphyry of south-most Brazil, with special attention of its colour variation. Anais do Primeiro Congresso Internacional de Rochas Ornamentais, CD, 2005b.

PENHA, A.E.P.P. $O$ calcário Caatinga de Ourolândia, Bahia: feições, diagnósticas, gênese e evolução de um perfil calcrete. Salvador: Universidade Federal da Bahia, 1994. (Master These, unpublished).

RIBEIRO, A.F., PEREIRA C.P., MAGALHÃES, A.C.F. Mármore Bege Bahia em Ourolândia-MirangabaJacobina, Bahia: geologia, potencialidade e desenvolvimento sustentável. Salvador: CBPM, 2002. (Série Arquivos Abertos).

Artigo recebido em 03/04/2005 e aprovado em 25/05/2005.
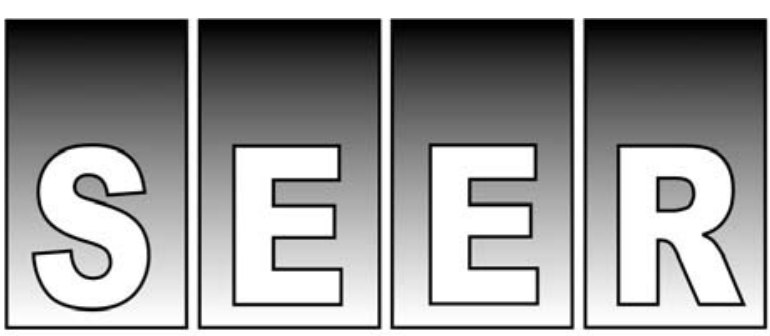



A questão SEER ou não SEER deixou de existir:

\section{Agora os autores utilizarão o SEER \\ para enviar e acompanhar seu artigo até o momento da publicação.}

\section{REM: 69 anos divulgando Ciência!}

